\title{
Anorpiment, $\mathrm{As}_{2} \mathrm{~S}_{3}$, the triclinic dimorph of orpiment
}

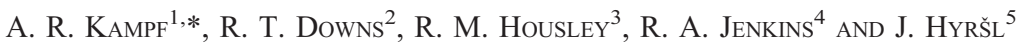 \\ 1 Mineral Sciences Department, Natural History Museum of Los Angeles County, 900 Exposition Boulevard, \\ Los Angeles, California 90007, USA \\ 2 Department of Geosciences, University of Arizona, Tucson, Arizona 85721-0077, USA \\ 3 Division of Geological and Planetary Sciences, California Institute of Technology, Pasadena, CA 91125, USA \\ 44521 N. Via Madre, Tucson, AZ 85749, USA \\ 5 Ke kurtum 383, 14200 Praha 4, Czech Republic
}

[Received 12 September 2011; Accepted 27 October 2011]

\section{ABSTRACT}

The new mineral anorpiment, $\mathrm{As}_{2} \mathrm{~S}_{3}$, the triclinic dimorph of orpiment, has space group $P \overline{1}$ and cell parameters $a=5.7577(2), b=8.7169(3), c=10.2682(7) \AA, \alpha=78.152(7), \beta=75.817(7), \gamma=$ 89.861(6) $)^{\circ}, V=488.38(4) \AA^{3}$ and $Z=4$. It occurs at the Palomo mine, Castrovirreyna Province, Huancavelica Department, Peru. It is a low-temperature hydrothermal mineral associated with dufrénoysite, muscovite, orpiment, pyrite and realgar. It occurs in drusy crusts of wedge-shaped, transparent, greenish yellow crystals. The streak is yellow. The lustre is resinous on crystal faces, but pearly on cleavage surfaces. The Mohs hardness is about $1 \frac{1}{2}$. The mineral is sectile with an irregular fracture and one perfect and easy cleavage on $\{001\}$. The measured and calculated densities are 3.33 and $3.321 \mathrm{~g} \mathrm{~cm}^{-3}$, respectively. All indices of refraction are greater than 2 . The mineral is optically biaxial (-) with $2 \mathrm{~V}=35-40^{\circ}$ and no observed dispersion. The acute bisectrix $(X)$ is approximately perpendicular to the $\{001\}$ cleavage. Electron microprobe analyses yielded the averages and ranges in wt.\%: As 58.21 (57.74-59.03), S 38.72 (38.33-39.00), total 96.94 (96.07-97.75), providing the empirical formula (based on 5 atoms) $\mathrm{As}_{1.96} \mathrm{~S}_{3.04}$. The strongest powder X-ray diffraction lines are

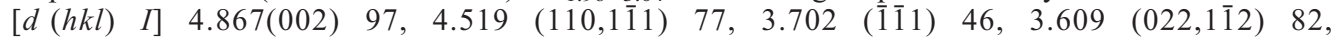
$2.880(201,0 \overline{2} 2, \overline{1} \overline{2} 1,023) 75,2.552(\overline{1} 13, \overline{1} 31,132) \quad 100,2.469(114,130,1 \overline{3} 1)$ 96. The structure of anorpiment $\left[R_{1}=0.021\right.$ for 1484 reflections with $\left.F_{\mathrm{o}}>4 \sigma(F)\right]$ consists of layers of covalently bonded As and $\mathrm{S}$ atoms. Each $\mathrm{S}$ atom bonds to two As atoms at As-S-As angles between 100.45 and $104.15^{\circ}$. Each As atom is strongly bonded to three $\mathrm{S}$ atoms at $\mathrm{S}-\mathrm{As}-\mathrm{S}$ angles between 91.28 and $103.59^{\circ}$, forming an $\mathrm{AsS}_{3}$ pyramid with $\mathrm{As}$ at its apex. The As-S linkages within the layers form rings of six $\mathrm{AsS}_{3}$ pyramids. Interlayer bonding forces are interpreted as van der Waals. The structure of anorpiment is similar to that of orpiment in that it is composed of layers of $\mathrm{As}_{2} \mathrm{~S}_{3}$ macromolecules, but arranged in a different stacking sequence.

KEYWORDs: anorpiment, new mineral, crystal structure, orpiment, arsenic sulphide, van der Waals forces, Palomo mine, Peru.

\section{Introduction}

THE mines of Peru have yielded mineral riches for hundreds of years and, particularly since about 1980, have produced many remarkable mineral

*E-mail: akampf@nhm.org

DOI: $10.1180 /$ minmag.2011.075.6.2857 specimens (Crowley et al., 1997). During its years as an active mine, the Palomo mine was not known as a specimen producer; however, following the cessation of mining operations in 2000, a few independent miners began working the mine for mineral specimens. The relatively few specimens that had reached the collector market by 2008 were described in detail by Hyršl (2008). The most noteworthy specimen discov- 
eries occurred in 2006 and included some of the finest crystals of realgar known from Peru, as well as unusual pseudomorphs of orpiment after realgar.

Following the publication of the article by Hyršl (2008), a small number of specimens containing unusual yellowish green crystalline druses were produced. These were said to be orpiment; however, Raman spectroscopy conducted on one such specimen by one of the authors (RAJ) showed the material to be distinct from orpiment. Further study confirmed the crystals to be a new species, the triclinic dimorph of orpiment.

The new mineral is named anorpiment for its triclinic (anorthic) symmetry and its dimorphous relationship to orpiment. The new mineral and name have been approved by the Commission on New Minerals, Nomenclature and Classification of the International Mineralogical Association (IMA 2011-014). Two cotype specimens are deposited in the Natural History Museum of Los Angeles County, catalogue numbers 63514 and 63544. One cotype is deposited in the collections of the Mineral Museum of the University of Arizona, catalogue number 19326.

The discovery of a new polymorph of $\mathrm{As}_{2} \mathrm{~S}_{3}$ is remarkable given the large amount of work that has been done on the synthesis and phase relationships of arsenic sulphides due to interest in their optical and electronic properties (Srivastava et al., 2011) and especially at hightemperatures, because $\mathrm{As}_{2} \mathrm{~S}_{3}$ is an excellent glass former (Espeau et al., 2006). The known natural phases of arsenic sulphide include the molecular crystals dimorphite, $\mathrm{As}_{4} \mathrm{~S}_{3}$; pararealgar, $\mathrm{As}_{4} \mathrm{~S}_{4}$; realgar, $\mathrm{As}_{4} \mathrm{~S}_{4}$; alacránite, $\mathrm{As}_{8} \mathrm{~S}_{9}$; and uzonite, $\mathrm{As}_{4} \mathrm{~S}_{5}$; and the layer structure orpiment, $\mathrm{As}_{2} \mathrm{~S}_{3}$ (Gibbs et al., 2011). A poorly described mineral with unknown structure, duranusite, $\mathrm{As}_{4} \mathrm{~S}$, is also known. An additional natural occurrence of $\beta-\mathrm{As}_{4} \mathrm{~S}_{4}$ was described by Burns and Percival (2001) in a drill core from Papua New Guinea and again reported from Radvanice, Bohemia (rruff.info/R061028) by the RRUFF project.

Solid $\mathrm{As}_{2} \mathrm{~S}_{3}$ was previously known in only two phases, glass and crystalline orpiment. According to Besson et al. (1980), most of its known glass properties have been derived from studies of the crystalline state and they remark that the relationship between the nearest-neighbour bonding topologies of crystalline and amorphous $\mathrm{As}_{2} \mathrm{~S}_{3}$ is essentially that envisaged by Zachariasen in his classic 1932 paper describing what has since become known as the 'continuous-randomnetwork model' for the structure of glasses.

Orpiment is also notable as the layer crystal for which the crucial role of the two-dimensional 'macromolecule' was first appreciated and analysed (Espeau et al., 2006). Both Besson et al. (1980) and Espeau et al. (2006) spent considerable effort in attempts to synthesize a new $\mathrm{As}_{2} \mathrm{~S}_{3}$ polymorph and summarized their work as follows: "Thus the existence of another enantiotropically related $\mathrm{As}_{2} \mathrm{~S}_{3}$ polymorph remains elusive" and " $\mathrm{As}_{2} \mathrm{~S}_{3}$ is unusual in that, unlike the majority of layer crystals, it does not exhibit any polytypism (polymorphism involving rearrangements of the layer stacking) at ambient conditions."

\section{Occurrence}

Anorpiment was found at the Palomo (or El Palomo) mine, Castrovirreyna Province, Huancavelica Department, Peru. The mine is at an altitude of almost $5,000 \mathrm{~m}$ and is located between the much more famous Julcani and San Genaro mining districts.

The Palomo mine belongs metallogenetically to the Huachocolpa ore district. The rocks in the area of the mine are exclusively volcanic, comprising andesitic lavas, pyroclastic rocks, tuffs and breccias. All of the mineralized veins are found within these rocks. An intrusive diorite stock has been identified at depth and it is believed to be responsible for the mineralization.

The mineralization is characterized by banded vein fillings of rhodochrosite, with calcite, baryte and quartz occurring as common gangue minerals. The main ore minerals are pyrite, galena, sphalerite and chalcopyrite, and much less commonly tetrahedrite and the silver sulphosalts, pyrargyrite, proustite, polybasite and seligmannite. Realgar, orpiment and stibnite are common in the outer parts of the deposit (Hyršl, 2008). Anorpiment is also found in the outer portion of the deposit, but is very rare. It is interpreted as being a relatively low-temperature hydrothermal mineral. On the type specimens, anorpiment is associated with dufrénoysite, muscovite, orpiment, pyrite and realgar, all of which formed earlier in the paragenesis.

\section{Physical and optical properties}

Anorpiment forms drusy coatings of wedgeshaped crystals up to $0.2 \mathrm{~mm}$ in their maximum 


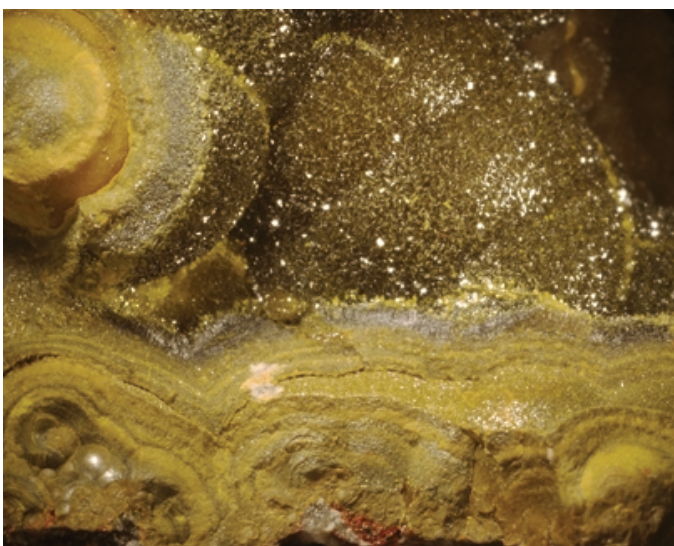

FIG. 1. Drusy coating of anorpiment on orpiment with minor realgar; field of view $12 \mathrm{~mm}$ across.

dimension (Fig. 1). The crystals are typically oriented with their (001) faces approximately parallel to the surface on which the druse is growing, so that specimens exhibit numerous reflections from the (001) faces (Fig. 2). On some specimens, the (001) face is not developed and crystals come to a sharp pointed termination. The crystal forms include $\{010\},\{110\},\{\overline{1} 10\}$, $\{001\},\{021\}$ and $\{0 \overline{2} 1\}$ (Fig. 3). The faces of the $\{110\}$ and $\{\overline{1} 10\}$ forms are typically incompletely formed and cavernous (Fig. 2).

Anorpiment crystals are transparent and greenish yellow. The streak is yellow. The lustre is resinous on crystal faces, but pearly on cleavage surfaces. The Mohs hardness is $\sim 1 \frac{1}{2}$. The mineral is sectile with irregular fracture and one perfect and easy cleavage on $\{001\}$. The measured, calculated and ideal densities are 3.33, 3.321 and $3.346 \mathrm{~g} \mathrm{~cm}^{-3}$, respectively.

All indices of refraction are greater than 2 . The mineral is optically biaxial (-) with $2 \mathrm{~V}=35-40^{\circ}$ and no observed dispersion. The acute bisectrix $(X)$ is approximately perpendicular to the $\{001\}$ cleavage.

\section{Raman spectroscopy}

Raman spectra were collected using a $532 \mathrm{~nm}$ incident laser on a Thermo Almega XR Raman spectrophotometer. Data were collected with 20 scans at $10 \mathrm{~s}$ each, run at $50 \%$ power. At full power there was a slight darkening of the sample after $10 \mathrm{~s}$; however, the spectrum did not change. In Fig. 4, the Raman spectrum of anorpiment is compared to that of orpiment. Although it is clear that the two phases can be distinguished from each other by their Raman spectra, it is notable that there is no large difference in the number of

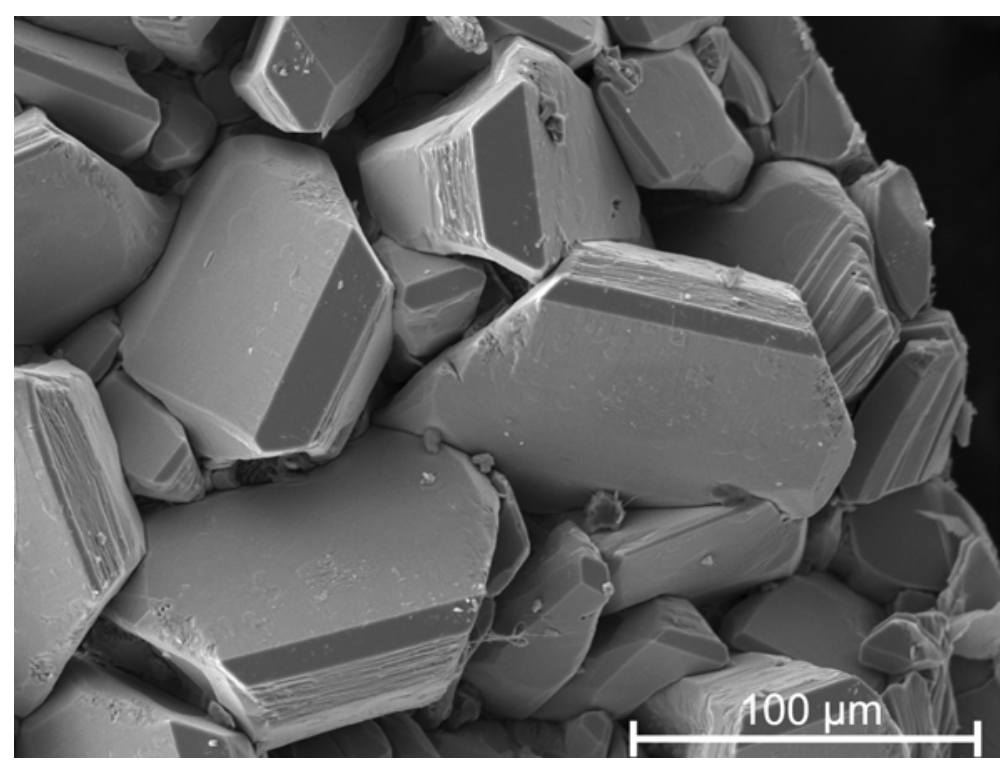

FIG. 2. A scanning electron microscope image of anorpiment crystals. Note narrow and dark (001) faces, oriented approximately parallel to the surface on which the druse is growing. 


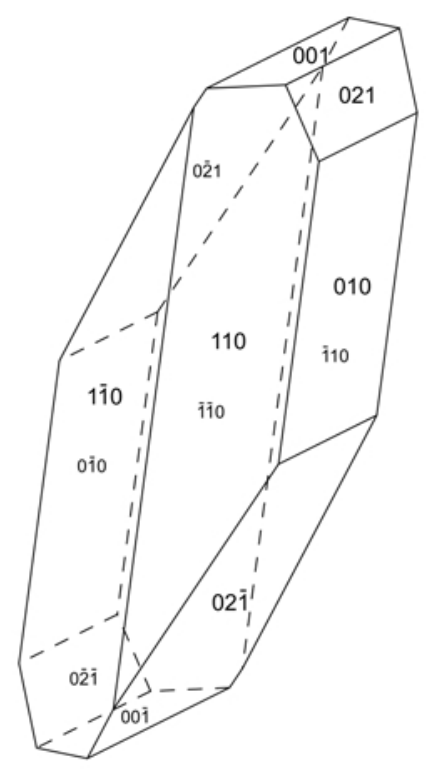

FIG. 3. A crystal drawing of anorpiment (clinographic projection in standard orientation). The rear (hidden) edges are shown as dashed lines and the Miller indices of the rear faces are in a slightly smaller font size. Note that only the faces in the upper half of the drawing are generally observed, producing a wedge-like habit in natural crystals. peaks between the two. In general, it is expected that lower symmetry phases have more peaks than their higher symmetry counterparts; however, in this case, the As-S bond length as well as the As-S-As and $\mathrm{S}-\mathrm{As}-\mathrm{S}$ angle distributions are narrow and similar between the two and, consequently, there are related modes that are nearly degenerate. The vibrational spectrum of orpiment has been described in detail by Zallen et al. (1971), and it is expected that their analysis can be applied to anorpiment.

\section{Chemistry}

Several grains were mounted in epoxy resin and polished for microprobe analysis. The polished surface was coated with $120 \mathrm{~nm}$ of carbon and examined in a Philips XL30 FESEM equipped with a Link Tetra backscattered electron detector, an Oxford INCA thin window EDS detector and an IMIX analysis system. High statistical precision analyses using energy-dispersive spectrometry (EDS) showed only As and S. No other elements were detected. In particular $\mathrm{Sb}$ and $\mathrm{Se}$ were below the estimated 0.1 atom percent detection limits. Backscattered electron imaging showed that the grains contain appreciable fine-

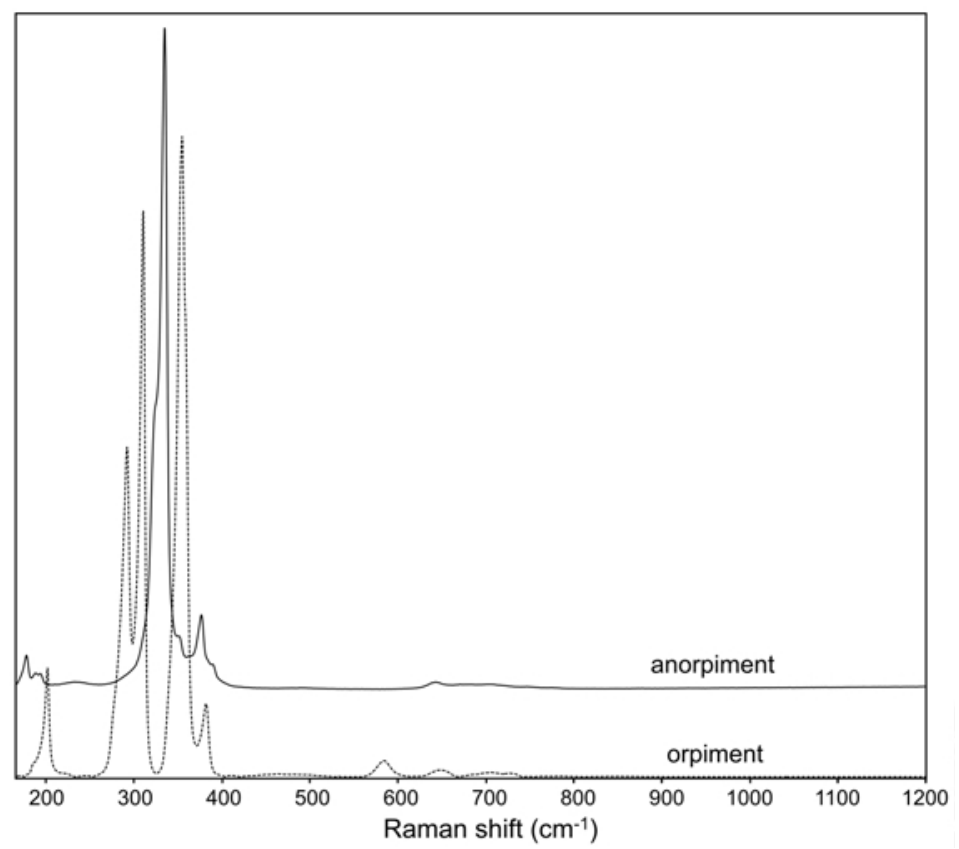

FIG. 4. Raman spectra of orpiment and anorpiment. 
scale porosity, partly from pre-existing pores and partly developed along the $\{001\}$ cleavage plane, possibly during polishing.

More accurate chemical analyses (4) were subsequently carried out using a JEOL 8200 electron microprobe in the Division of Geological and Planetary Sciences, California Institute of Technology (in wavelength-dispersive mode, operating at $15 \mathrm{kV}, 5 \mathrm{nA}$, with a $20 \mu \mathrm{m}$ beam diameter). Quantitative elemental microanalyses were processed with the CITZAF correction procedure. The averages and ranges are as follows: As 58.21 (57.74-59.03), S 38.72 (38.33-39.00), total 96.94 (96.07-97.75), providing the empirical formula (based on 5 atoms) $\mathrm{As}_{1.96} \mathrm{~S}_{3.04}$. The low totals are attributed to the fine-scale porosity mentioned above. The ideal formula is $\mathrm{As}_{2} \mathrm{~S}_{3}$, which requires As 60.91, S 39.09, total 100.00 wt.\%. Anorpiment is insoluble in concentrated $\mathrm{HCl}$.

TABLE 1. X-ray powder diffraction data for anorpiment.

\begin{tabular}{|c|c|c|c|c|c|c|c|c|c|}
\hline$I_{\mathrm{obs}}$ & $d_{\mathrm{obs}}$ & $d_{\text {calc }}$ & $I_{\text {calc }}$ & $h k l$ & $I_{\mathrm{obs}}$ & $d_{\text {obs }}$ & $d_{\text {calc }}$ & $I_{\text {calc }}$ & $h k l$ \\
\hline & & 4.8654 & 100 & $\begin{array}{lll}0 & 0 & 2\end{array}$ & 7 & $2.032(7)$ & 2.0388 & 5 & 115 \\
\hline \multirow[t]{3}{*}{97} & \multirow[t]{2}{*}{$4.867(3)$} & 4.7769 & 15 & $\overline{1} 10$ & 7 & $2.010(5)$ & 2.0177 & 4 & $2 \overline{2} 3$ \\
\hline & & 4.7496 & 10 & 111 & 15 & $1.9434(9)$ & 1.9432 & 16 & $0 \overline{2} 4$ \\
\hline & \multirow{2}{*}{$4.519(5)$} & 4.5609 & 30 & 110 & \multirow{6}{*}{17} & \multirow{6}{*}{$1.862(7)$} & 1.8732 & 2 & $\begin{array}{lll}3 & \overline{1} & 1\end{array}$ \\
\hline 77 & & 4.4602 & 27 & $\begin{array}{lll}1 & \overline{1} & 1\end{array}$ & & & 1.8649 & 4 & $\begin{array}{lll}3 & 1 & 1\end{array}$ \\
\hline 18 & $4.272(6)$ & 4.2602 & 28 & $0 \underset{-1}{2} 0$ & & & 1.8439 & 5 & $\begin{array}{lll}3 & 112\end{array}$ \\
\hline 46 & $3.702(9)$ & 3.7027 & 31 & $\begin{array}{lll}\overline{1} & \overline{1} & 1\end{array}$ & & & 1.841 & 5 & $\overline{2} 23$ \\
\hline \multirow{2}{*}{82} & \multirow[b]{2}{*}{$3.609(3)$} & 3.6045 & 62 & 022 & & & 1.8239 & 5 & 205 \\
\hline & & 3.5844 & 32 & $1 \overline{1} 2$ & & & 1.8155 & 21 & $0 \overline{4} 2$ \\
\hline \multirow{4}{*}{8} & \multirow{3}{*}{$3.480(5)$} & 3.4777 & 4 & 121 & \multirow[t]{4}{*}{42} & \multirow[t]{4}{*}{$1.8169(7)$} & 1.8022 & 3 & 044 \\
\hline & & 3.4705 & 6 & $\overline{1} 20$ & & & 1.7969 & 4 & 310 \\
\hline & & 3.3055 & 8 & 120 & & & 1.7866 & 4 & 225 \\
\hline & \multirow{3}{*}{$3.273(2)$} & 3.2819 & 8 & $\begin{array}{lll}\overline{1} & 0 & 2\end{array}$ & & & 1.7557 & 6 & $3 \overline{1} 3$ \\
\hline \multirow{3}{*}{27} & & 3.2564 & 9 & $\begin{array}{lll}\overline{1} & 1 & 2\end{array}$ & \multirow[t]{3}{*}{20} & \multirow[t]{3}{*}{$1.7457(6)$} & 1.7449 & 12 & $\overline{1} 15$ \\
\hline & & 3.2519 & 6 & $1 \overline{2} 1$ & & & 1.7404 & 5 & $\begin{array}{lll}32 & 1\end{array}$ \\
\hline & \multirow{3}{*}{$3.162(2)$} & 3.1688 & 7 & 103 & & & 1.7089 & 10 & 116 \\
\hline \multirow{2}{*}{20} & & 3.159 & 9 & 113 & \multirow{4}{*}{40} & \multirow[t]{2}{*}{$1.7073(11)$} & 1.704 & 6 & $\overline{2} 33$ \\
\hline & & 2.9146 & 11 & $0 \overline{2} 2$ & & & 1.7035 & 4 & $2 \overline{4} 1$ \\
\hline & \multirow{3}{*}{$2.880(4)$} & 2.8917 & 6 & 023 & & & 1.6831 & 7 & $\overline{3} \overline{1} 1$ \\
\hline \multirow{2}{*}{75} & & 2.8768 & 55 & $\begin{array}{lll}2 & 0 & 1\end{array}$ & & \multirow{6}{*}{$1.6667(6)$} & 1.6665 & 9 & 152 \\
\hline & & 2.8691 & 9 & $\overline{1} \overline{2} 1$ & \multirow[t]{5}{*}{27} & & 1.6661 & 9 & 151 \\
\hline 16 & $2.815(14)$ & 2.8036 & 8 & $1 \overline{2} 2$ & & & 1.6645 & 4 & 235 \\
\hline & & 2.6898 & 10 & $\overline{2} 10$ & & & 1.6438 & 4 & $0 \overline{2} 5$ \\
\hline 16 & $2.6 / 0(2)$ & 2.6544 & 10 & 212 & & & 1.637 & 5 & $\overline{2} \overline{2} 3$ \\
\hline & & 2.5715 & 29 & $\begin{array}{lll}\overline{1} & 1 & 3\end{array}$ & & & 1.6313 & 6 & $3 \overline{1} 4$ \\
\hline 100 & $2.552(6)$ & 2.546 & 26 & $\begin{array}{lll}\overline{1} & 3 & 1\end{array}$ & 40 & $1.6251(10)$ & 1.6218 & 4 & $\begin{array}{lll}0 & 0 & 6\end{array}$ \\
\hline & & 2.5336 & 22 & 132 & & & 1.6168 & 5 & 045 \\
\hline & & 2.5183 & 10 & $\begin{array}{lll}\overline{2} & 0 & 1\end{array}$ & & & 1.6149 & 5 & $\overline{1} 35$ \\
\hline & & 2.5013 & 31 & 114 & & & 1.5896 & 5 & 136 \\
\hline 96 & $2.469(8)$ & 2.4805 & 32 & 130 & 18 & $1.5868(8)$ & 1.5848 & 5 & $2 \overline{2} 5$ \\
\hline & & 2.4514 & 29 & $1 \overline{3} 1$ & & & 1.5805 & 4 & $\begin{array}{lll}3 & 31 & 1\end{array}$ \\
\hline & & 2.4363 & 5 & 203 & & & 1.5576 & 11 & $\overline{1} 53$ \\
\hline & & 2.4327 & 15 & $\begin{array}{lll}0 & 04\end{array}$ & & & 1.5515 & 5 & $\overline{2} \overline{4} 1$ \\
\hline 13 & $2.340(3)$ & 2.3355 & 7 & 024 & 42 & $1.5504(5)$ & 1.5478 & 10 & 154 \\
\hline 11 & $2.2706(11)$ & 2.2698 & 15 & $\overline{2} 21$ & & & 1.5407 & 4 & $\overline{2} 43$ \\
\hline 22 & $2.2285(15)$ & 2.2277 & 15 & 223 & & & 1.5259 & 4 & $\overline{1} \overline{3} 4$ \\
\hline 9 & $2.1358(10)$ & 2.1301 & 11 & 040 & & & 1.5197 & 5 & $2 \overline{4} 3$ \\
\hline 11 & $2.0776(21)$ & 2.0885 & 6 & $\overline{1} 14$ & 17 & $1.5171(8)$ & 1.5142 & 4 & 245 \\
\hline 11 & $2.07 / 0(21)$ & 2.0785 & 3 & $\overline{2} \overline{2} 1$ & & & 1.5005 & 4 & $1 \overline{3} 5$ \\
\hline
\end{tabular}


X-ray crystallography and structure determination

Both powder and single-crystal X-ray diffraction data were obtained on a Rigaku R-Axis Rapid II curved imaging plate microdiffractometer using monochromatic Mo- $K \alpha$ radiation. Observed powder $d$ spacings (with standard deviations) and intensities were derived by profile fitting using JADE 9.3 software. Data (in A for Mo- $K \alpha$ ) are given in Table 1. The recorded pattern is compared to those simulated from the structures of anorpiment and orpiment in Fig. 5. Unit-cell parameters refined from the powder data using $J A D E 9.3$ with whole pattern fitting are $a=5.755(3), b=8.724(3), c=10.280(3) \AA$, $\alpha=78.129(8), \beta=75.724(10), \gamma=89.913(7)^{\circ}$ and $V=488.8(3) \AA^{3}$.
The Rigaku Crystal Clear software package was used for processing the structure data including the application of an empirical absorption correction. The structure was solved by direct methods using SIR2004 (Burla et al., 2005); SHELXL-97 software (Sheldrick 2008) was used, with neutral atom scattering factors, for the refinement of the structure.

Details of the data collection and structure refinement are provided in Table 2. The final atom coordinates and displacement parameters are listed in Table 3. Selected interatomic distances and angles are listed in Table 4.

\section{Description of the structure}

The structure of anorpiment consists of layers of covalently bonded As and S atoms. Each S atom

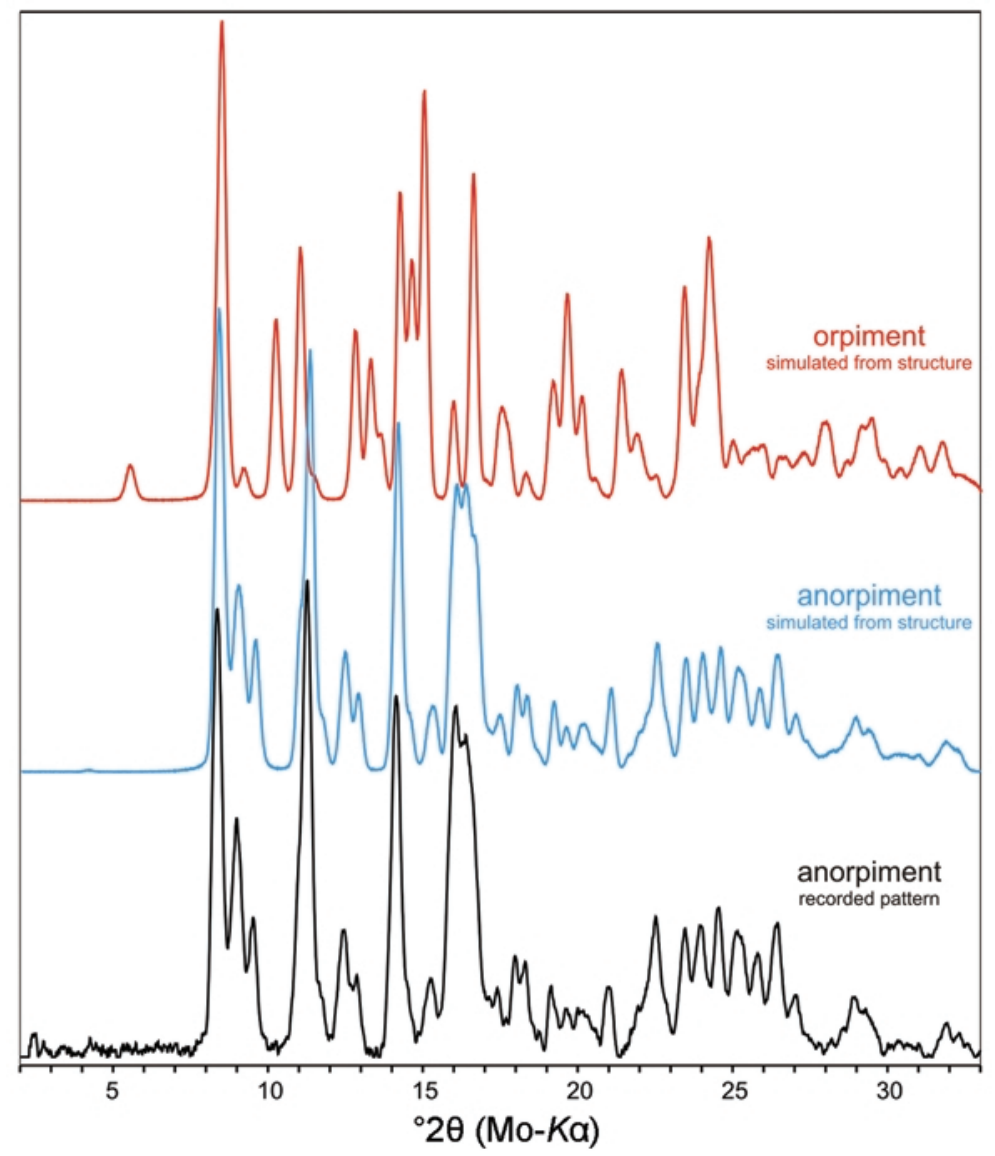

FIG. 5. The PXRD pattern using Mo- $K \alpha$ radiation for anorpiment compared to the patterns simulated from the structures of anorpiment and orpiment (Mullen and Nowacki, 1972) using JADE 9.3. 
TABLE 2. Data collection and structure refinement details for anorpiment.

Diffractometer

$\mathrm{X}$-ray radiation/power

Temperature

Structural Formula

Space group

Unit-cell dimensions

Z

Volume

Density (for above formula)

Absorption coefficient

$F(000)$

Crystal size

$\theta$ range

Index ranges

Reflections collected/unique

Reflections with $F_{\mathrm{o}}>4 \sigma F$

Completeness to $\theta=25.02^{\circ}$

Max. and min. transmission

Absorption correction

Refinement method

Parameters refined

GoF

Final $R$ indices $\left[F_{\mathrm{o}}>4 \sigma F\right]$

$R$ indices (all data)

Largest diff. peak/hole

Flack parameter

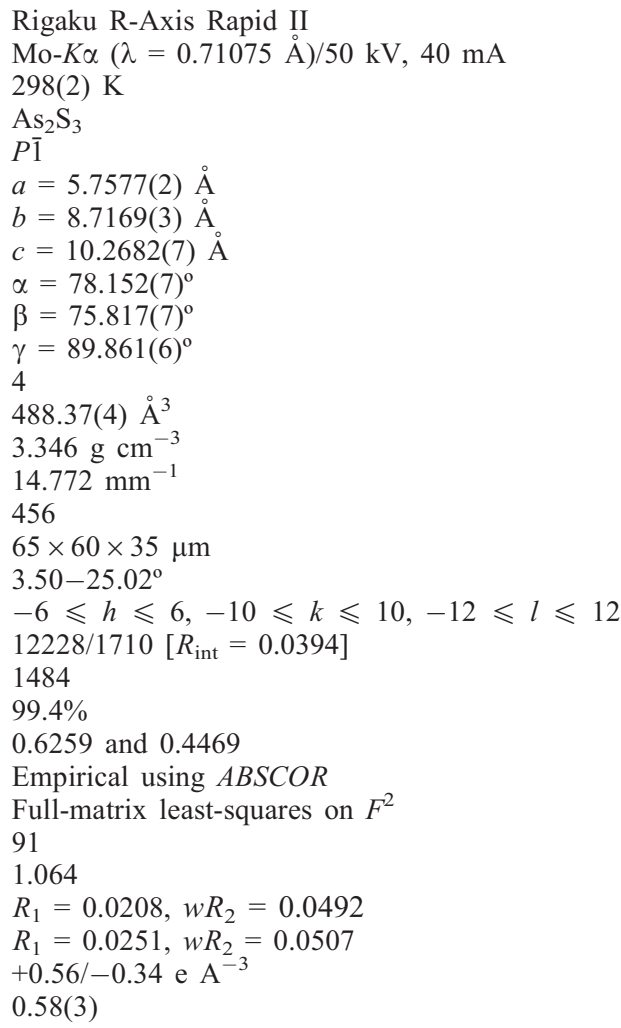

Notes: $R_{\text {int }}=\Sigma \mid F_{\mathrm{o}}^{2}-F_{\mathrm{o}}^{2}($ mean $) \mid / \Sigma\left[F_{\mathrm{o}}^{2}\right] ;$

$\mathrm{GoF}=S=\left\{\Sigma\left[w\left(F_{\mathrm{o}}^{2}-F_{\mathrm{c}}^{2}\right)^{2}\right] /(n-p)\right\}^{1 / 2}$;

$R_{1}=\Sigma|| F_{\mathrm{o}}|-| F_{\mathrm{c}}|/ / \Sigma| F_{\mathrm{o}} \mid$

$w R_{2}=\left\{\Sigma\left[w\left(F_{\mathrm{o}}^{2}-F_{\mathrm{c}}^{2}\right)^{2}\right] / \Sigma\left[w\left(F_{\mathrm{o}}^{2}\right)^{2}\right]\right\}^{1 / 2}$;

$w=1 /\left[\sigma^{2}\left(F_{\mathrm{o}}^{2}\right)+(a P)^{2}+b P\right]$ where $a$ is $0.0242, b$ is 0.2186 and $P$ is $\left[2 F_{\mathrm{c}}^{2}+\operatorname{Max}\left(F_{\mathrm{o}}^{2}, 0\right)\right] / 3$.

bonds to two As atoms at As-S-As angles between 100.45 and $104.15^{\circ}$. Each As atom bonds to three $\mathrm{S}$ atoms at $\mathrm{S}-\mathrm{As}-\mathrm{S}$ angles between 91.28 and $103.59^{\circ}$, forming an $\mathrm{AsS}_{3}$ pyramid with As at its apex. The As-S linkages within the layers form rings of six $\mathrm{AsS}_{3}$ pyramids. Interlayer bonding is via van der Waals forces (Gibbs et al., 2010, 2011). As shown in Fig. 6, the structure of anorpiment is similar to that of orpiment (Mullen and Nowacki, 1972). The layers in both structures can be viewed as linkages between $\mathrm{AsS}_{3}$ pyramids and in both cases the layers contain six-membered rings of pyramids. In orpiment, pairs of adjacent $\mathrm{AsS}_{3}$ pyramids have their As apices oriented in approximately the same direction, whereas in anorpiment the As apex of each pyramid points in an approximately opposite direction to that of the adjacent pyramid (Fig. 7). Therefore, anorpiment and orpiment are not polytypes. The unit-cell parameters and densities of orpiment and anorpiment are compared in Table 5.

Besson et al. (1980) stated that the structure of orpiment can be visualized as corrugated layers with the 'thick' portions of one layer nesting over the 'thin' portions of the next. In the language of their model, it could be said that pairs of layers in anorpiment are nested with the 'thick' portions over the 'thick' portions, and the 'thin' over the 


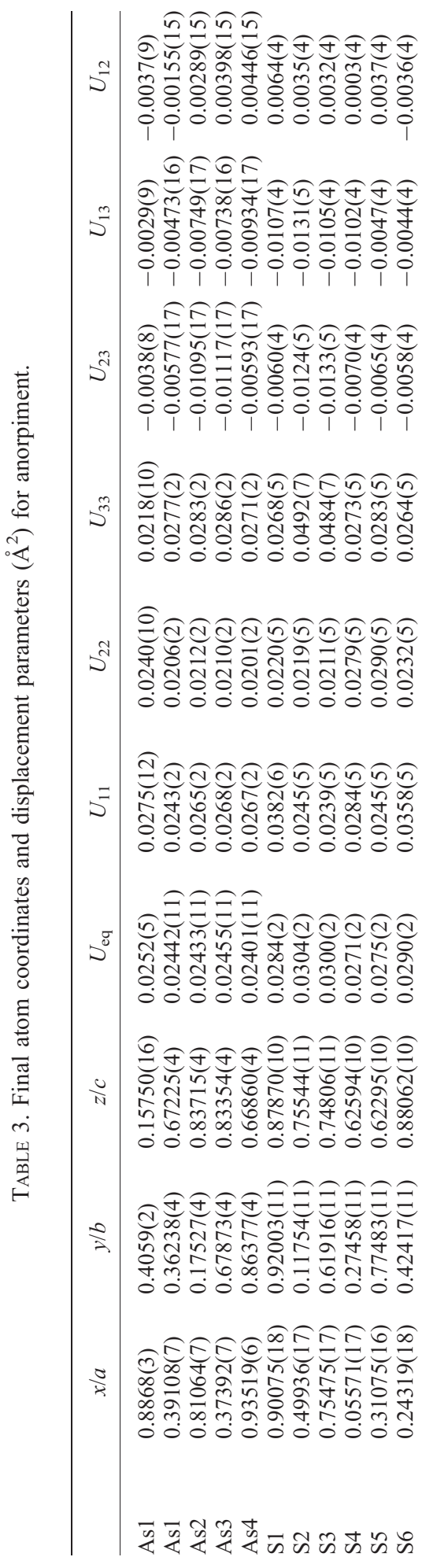

'thin', and these pairs are then stacked in a similar manner to orpiment.

Gibbs et al. (2010) computed the electron density distribution for orpiment, which indicated that there is a network of weak van der Waals (vdw) bonds in As-S, S-S and As-As pairs both between layers and holding the corrugated portions together, and it is these bonds that stabilize the crystalline structure. A procrystal analysis (Downs et al., 2002) of anorpiment was conducted to determine whether a similar network was present. The procrystal analysis indicated that there were $43 \mathrm{vdw}$ bonds, compared to 52 reported in orpiment. This could indicate weaker interlayer bonding in anorpiment, consistent with its lower density. In addition, it is interesting to note that there were one-third the number of vdw As $-\mathrm{S}$ bonds in anorpiment, but increased numbers of $\mathrm{S}-\mathrm{S}$ and $\mathrm{As}-\mathrm{As}$ vdw bonds. A full $a b$ initio calculation is required to completely characterize the nature of these bonds.

\section{The $A s_{2} \mathrm{~S}_{3}$ arsenic sulphides}

A question naturally arises as to whether anorpiment is a metastable polymorph or if it has a place on the pressure and temperature equilibrium phase diagram of the arsenic sulphides. The arsenic sulphides have been studied for many years, and so it is surprising to find a new natural polymorph. Given that the density of anorpiment $\left(3.346 \mathrm{~g} \mathrm{~cm}^{-3}\right)$ is less than that of orpiment $\left(3.494 \mathrm{~g} \mathrm{~cm}^{-3}\right)$, it would seem that anorpiment is a high-temperature polymorph of $\mathrm{As}_{2} \mathrm{~S}_{3}$. However, in spite of years of experimentation at high temperatures, the phase has never been reported. Direct synthesis from a stoichiometric mixture of elemental As and $\mathrm{S}$ usually yields a vitreous solid that is notoriously difficult to crystallize except by annealing for long periods at temperatures between 500 and $580 \mathrm{~K}$. Espeau et al. (2006) synthesized orpiment by annealing the glass at $523 \mathrm{~K}$ for $1 \mathrm{y}$.

There are some reports hinting at the possibility of a high temperature polymorph. Kirkinskii et al. (1967) described a reversible transformation of orpiment, based on an endothermic effect around 443-447 K. Pascal (1958) reported a new form of $\mathrm{As}_{2} \mathrm{~S}_{3}$ with a density of $3.252 \mathrm{~g} \mathrm{~cm}^{-3}$ that is formed above $540 \mathrm{~K}$. However, others have also searched for these new phases and could find no evidence for them (cf. Besson et al., 1980; Devaud et al., 1989). Espeau et al. (2006) in a recent DSC experiment joined the ranks of those 
TABLE 4. Selected bond distances $(\AA)$ and angles $\left({ }^{\circ}\right)$ for anorpiment.

\begin{tabular}{lllrll}
\hline & & & & \\
As1-S4 & $2.2687(10)$ & S4-As1-S6 & $102.18(4)$ & As2-S1-As4 & $100.78(4)$ \\
As1-S6 & $2.2741(10)$ & S4-As1-S2 & $94.11(4)$ & As2-S2-As1 & $100.96(4)$ \\
As1-S2 & $2.2757(10)$ & S6-As1-S2 & $96.01(4)$ & As3-S3-As4 & $100.54(4)$ \\
& & & & As1-S4-As2 & $103.95(4)$ \\
As2-S2 & $2.2548(10)$ & S2-As2-S1 & $91.28(4)$ & As4-S5-As3 & $104.15(4)$ \\
As2-S1 & $2.2615(10)$ & S2-As2-S4 & $94.62(4)$ & As3-S6-As1 & $100.45(4)$ \\
As2-S4 & $2.2758(11)$ & S1-As2-S4 & $103.34(4)$ & & \\
As3-S3 & $2.2553(10)$ & S3-As3-S6 & $91.84(4)$ & & \\
As3-S6 & $2.2612(10)$ & S3-As3-S5 & $93.74(4)$ & & \\
As3-S5 & $2.2694(11)$ & S6-As3-S5 & $103.59(4)$ & & \\
As4-S5 & $2.2674(10)$ & S5-As4-S1 & $101.68(4)$ & & \\
As4-S1 & $2.2712(11)$ & S5-As4-S3 & $93.98(4)$ & & \\
As4-S3 & $2.2743(10)$ & S1-As4-S3 & $95.90(4)$ & & \\
& & & & & \\
\hline
\end{tabular}
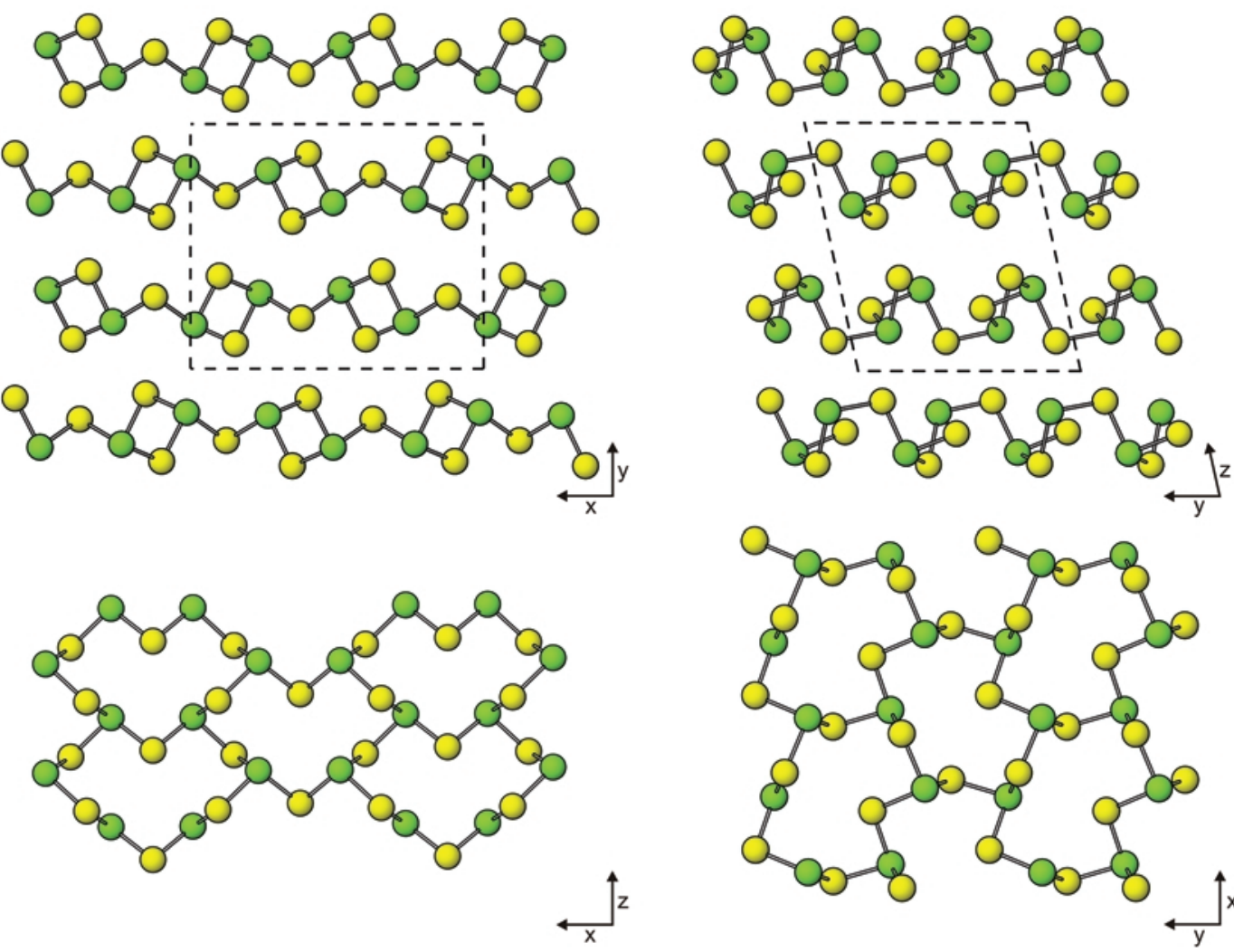

orpiment

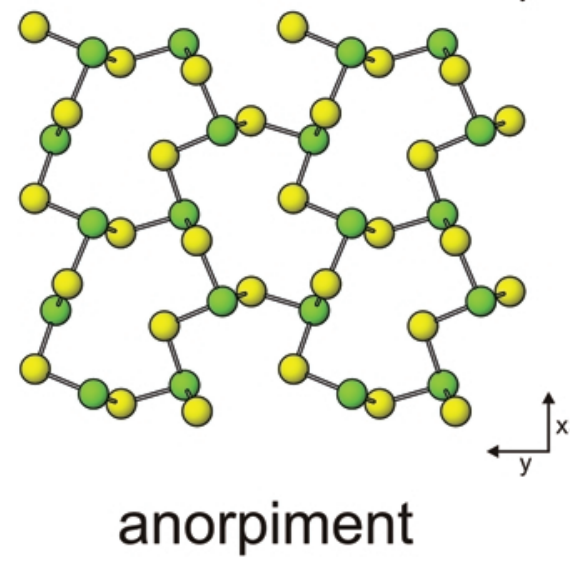

FIG. 6. The structures of orpiment and anorpiment viewed parallel (top) and perpendicular (bottom) to the sheet. 


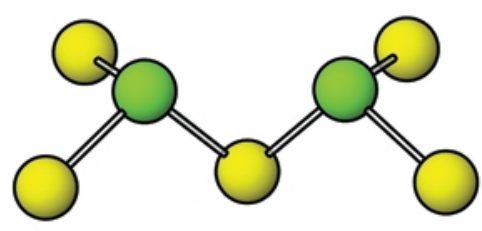

orpiment

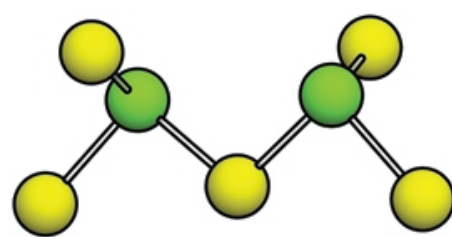

anorpiment

FIG. 7. Different As-S linkages in orpiment and anorpiment.

who could find no evidence for a high-temperature polymorph of $\mathrm{As}_{2} \mathrm{~S}_{3}$ and summarized their study with the statement "Thus the existence of another enantiotropically related $\mathrm{As}_{2} \mathrm{~S}_{3}$ polymorph remains elusive."

Besson et al. (1980) in their study of the effects of pressure on crystalline $\mathrm{As}_{2} \mathrm{~S}_{3}$ to $10 \mathrm{GPa}$ were motivated specifically to find a solid-state transition, but concluded that it did not exist. They summarized the previous work by concluding that, unlike the majority of layer crystals, $\mathrm{As}_{2} \mathrm{~S}_{3}$ does not exhibit any polytypism (polymorphism involving rearrangements of the layer stacking) at ambient conditions. The structure of corrugated layers can be visualized as the 'thick' portions of one layer nesting over the 'thin' portions of the next. They suggested that this method of fitting the layers together can be achieved efficiently in only one way.

The geological setting of the anorpiment reported in this study is consistent with formation in a relatively low-temperature hydrothermal

TABLE 5. Comparison of cell parameters and densities of orpiment and anorpiment.

\begin{tabular}{lll}
\hline & Orpiment* & Anorpiment \\
\hline Crystal system & Monoclinic & Triclinic \\
Space group & $P 2_{1} / n$ & $P \overline{1}$ \\
$a(\AA)$ & $11.475(5)$ & $5.7577(2)$ \\
$b(\AA)$ & $9.577(4)$ & $8.7169(3)$ \\
$c(\AA)$ & $4.256(2)$ & $10.2682(7)$ \\
$\alpha\left({ }^{\circ}\right)$ & & $78.152(7)$ \\
$\beta\left({ }^{\circ}\right)$ & $90.68(8)$ & $75.817(7)$ \\
$\gamma\left({ }^{\circ}\right)$ & 4 & $89.861(6)$ \\
$Z$ & 4 \\
$V\left(\AA^{\circ}\right)$ & $467.7(4)$ & $488.37(4)$ \\
$D_{\text {calc }}\left(\mathrm{g} \mathrm{cm}^{-3}\right)$ & 3.494 & 3.346 \\
\hline
\end{tabular}

*Mullen and Nowacki (1972). process, which, when coupled with the synthesis studies, further demonstrates that anorpiment is not likely to be found on the $P-T$ equilibrium phase diagram of the arsenic sulphides. Instead it appears that it formed under conditions stabilized by non-equilibrium processes such as templating or perhaps even as a result of biogenic processes.

\section{Acknowledgements}

Luca Bindi and an anonymous reviewer provided helpful comments on the manuscript. The microprobe analyses were supported by a grant to Caltech from the Northern California Mineralogical Association. Support from the Arizona Science Foundation and the RRUFF project is acknowledged by RTD. The remainder of this study was funded by the John Jago Trelawney Endowment to the Mineral Sciences Department of the Natural History Museum of Los Angeles County.

\section{References}

Besson, J.M., Cernogora, J. and Zallen, R. (1980) Effect of pressure on optical properties of crystalline $\mathrm{As}_{2} \mathrm{~S}_{3}$. Physical Review B, 22, 3866-3876.

Burla, M.C., Caliandro, R., Camalli, M., Carrozzini, B., Cascarano, G.L., De Caro, L., Giacovazzo, C., Polidori, G. and Spagna, R. (2005) SIR2004: an improved tool for crystal structure determination and refinement. Journal of Applied Crystallography, 38, 381-388.

Burns P.C. and Percival J.B. (2001) Alacranite, $\mathrm{As}_{4} \mathrm{~S}_{4}$ : a new occurrence, new formula, and determination of the crystal structure. The Canadian Mineralogist, 39, 809-818.

Crowley, J.A., Currier, R.H. and Szenics, T. (1997) Mines and minerals of Peru. Mineralogical Record, 28, 1-98.

Devaud, G., Aziz, M.J. and Turnbull, D. (1989) Highpressure crystallization kinetics of $\mathrm{As}_{2} \mathrm{~S}_{3}$. Journal of 
Non-Crystalline Solids, 109, 121-128.

Downs, R.T., Gibbs, G.V., Boisen, M.B., Jr. and Rosso, K.M. (2002) A comparison of procrystal and $a b$ initio representations of the electron-density distributions of minerals. Physics and Chemistry of Minerals, 29, 369-385.

Espeau, P., Tamarit, J.L., Barrio, M., López, D.Ó., Perrin, M.A., Allouchi, H. and Céolin, R. (2006) Solid state studies on synthetic and natural crystalline arsenic(III) sulfide, $\mathrm{As}_{2} \mathrm{~S}_{3}$ (orpiment): new data for an old compound. Chemistry of Materials, 18, $3821-3826$.

Gibbs, G.V., Wallace, A.F., Zallen, R., Downs, R.T., Ross, N.L., Cox, D.F. and Rosso, K.M. (2010) Bond paths and van der Waals interactions in orpiment, $\mathrm{As}_{2} \mathrm{~S}_{3}$. Journal of Physical Chemistry A, 114, 6550-6557.

Gibbs, G.V., Wallace, A.F., Downs, R.T., Ross, N.L., Cox, D.F. and Rosso, K.M. (2011) Thioarsenides: a case for long-range Lewis acid-base-directed van der Waals interactions. Physics and Chemistry of Minerals, 38, 267-291.

Hyršl, J. (2008) The Palomo mine, Huancavelica Department, Peru. Mineralogical Record, 39,
95-99.

Kirkinskii, V.A., Ryaposov, A.P. and Yakushev, V.G. (1967) Phase diagram of arsenic trisulfide at pressures up to 20 kbar. Izvestiya Akademii Nauk SSSR, Neoganicheskie Materialy, 3, 1931-1933.

Mullen, D.J.E. and Nowacki, W. (1972) Refinement of the crystal structures of realgar, AsS and orpiment, $\mathrm{As}_{2} \mathrm{~S}_{3}$. Zeitschrift für Kristallographie, 136, 48-65.

Pascal, P. (1958) Nouveau Traité de Chimie Minérale. Volume 11. Masson, Paris.

Sheldrick, G.M. (2008) SHELXL97 - Program for the refinement of crystal structures. University of Göttigen, Göttigen, Germany.

Srivastava P., Mund H.S. and Sharma, Y. (2011) Investigation of electronic properties of crystalline arsenic chalcogenides: theory and experiments. Physica B, 406, 3083-3088.

Zachariasen W.H. (1932) The atomic arrangement in glass. Journal of the American Chemical Society, 54, 3841-3851.

Zallen R., Slade M.L. and Ward A.T. (1971) Lattice vibrations and interlayer interactions in crystalline $\mathrm{As}_{2} \mathrm{~S}_{3}$ and $\mathrm{As}_{2} \mathrm{Se}_{3}$. Physical Review B, 3, 4257-4273. 
